www.jmscr.igmpublication.org

Impact Factor (SJIF): 6.379

Index Copernicus Value: 71.58

ISSN (e)-2347-176x ISSN (p) 2455-0450

crossref DOI: _https://dx.doi.org/10.18535/jmscr/v6i4.92

Journal Of Medical Science And Clinical Research

\title{
Role of Glycosylated Haemoglobin (HbA1c) as Predictor of Post-Operative Hyperglycemia and Complication after Major Gastro-Intestinal Surgery
}

\author{
Authors

\section{Dr Narendranath Swain ${ }^{1}$, Dr Y. Tejkumar ${ }^{2}$, Dr Jyoti Mohan Tosh ${ }^{3}$, Dr Manindra Nayak ${ }^{4}$}

${ }^{1,2}$ Associate Professor, Department of Surgery, SCB Medical College Cuttack, Odisha, India ${ }^{3}$ Junior Resident, $3^{\text {rd }}$ yr. Department of Surgery, SCB Medical College, Cuttack, Odisha, India

${ }^{4}$ Junior Resident, $2^{\text {nd }}$ yr, Department of Surgery, SCB Medical College, Cuttack, Odisha, India

Corresponding Author

Dr Y. Tejkumar

Email:drsidharth74@gmail.com

\begin{abstract}
Aim: Prediction of post operative complications from pre operative HbAlc levels \& its relation on post op. morbidity \& overall recovery of patient after major gastro-intestinal surgery.

Materials and Methods: A total no. of 60 patients who were planned for major GI surgery were taken into study and were divided into two groups as per pre- op HbAlc level ( $<6 \%$ or $>6 \%)$. The clinical data \& final results were analysed in relation to pre op. and post op. hyperglycemia.

Observation: It is observed that post-op. dayl FBS is raised in all patients, however post-op day 1 hyperglycemia is present in $60 \%$ of patients in $\mathrm{HbAlc}>6 \%$ and $22.5 \%$ in patients in $\mathrm{HbAlc}<6 \%$. The postop. complications occur more i.e. $65 \%$ in $\mathrm{HbAlc}>6 \%$ and $20 \%$ in $\mathrm{HbAlc}<6 \%$. The infectious complication is more i.e. $50 \%$ in $\mathrm{HbAlc}>6 \%$ and $5 \%$ in $\mathrm{HbAlc}<6 \%$. The post-op. recovery i.e. early bowel movement, early oral feeding are also delayed in $\mathrm{HbAlc}>6 \%$ group. The post-op. hospital staying is also more in this group. The post-op. CPR response is also significantly raised in HbAlc $>6 \%$ group.

Conclusion: That pre operative HbAlc may be used to identify patients at higher risk of poor post-op. glycemic control and prediction of post- op. complications, recovery \& morbidity after major gastrointestinal surgery.
\end{abstract}

Keywords: Hyperglycemia, HbAlc, Gastro intestinal surgery.

\section{Introduction}

Surgery like any trauma induces a complex series of hormonal and metabolic changes that increases secretion of cortisol, epinephrine, glucagon \& growth hormone during surgery and is associated with insulin resistance and hyperglycemia in diabetic patient. Metabolic stress \& insulin resistance are consequence of major surgery \& the resulting post-operative hyper-glycemia is associated with increased morbidity \& mortality. ${ }^{1}$ Individuals with Type-1 diabetes are at greater risk of metabolic complications if not managed adequately preoperatively. A diabetic patient spends $30-50 \%$ more time in hospital than a non 
diabetic following major surgery .Carefully managed diabetes does not add significantly to surgical risk. Most often it is poor glycemic control; inefficient monitoring facilities, pre existing unrecognised sepsis and diabetic complications which contributes to adverse outcome. $^{2}$ This study based on hypothesis that pre-operative plasma concentration of glycosylated $\mathrm{Hb}(\mathrm{HbA1c})$ a long term marker of glucose control, its correlation with post-operative glucose control, the magnitude of inflammatory response, post operative recovery and 30 days overall morbidity after major gastro-intestinal surgery.

\section{Aims \& Objectives}

1. Role of pre-operative $\mathrm{HbA1c}$ on postoperative hyperglycemia.

2. Prediction of postoperative complications from preoperative HbA1c level.

3. Relation of HbA1c (pre operative) on post-operative recovery and 30days overall morbidity after GI surgery.

\section{Materials \& Methods}

This study was conducted in SCB Medical college hospital Cuttack from October 2015 to December
2017. This is a prospective, hospital based, non -randomized interventional study. Approval from the ethical committee of the medical college was obtained for this study. All indoor patients admitted to the surgery deptt. Were enrolled for this study as per inclusion \& exclusion criteria. The exclusion criteras are haemoglobinopathies, haemolytic anaemia, uraemia \& complications of diabetes mellitus at the time of admission. A total no. of 60 patients out of 110 patients who were planned for major GI surgery were taken in this study. Detailed history of individual patient, all routine blood investigations, necessary imagings, pre- operative cardiology \& pulmonary assessments were done. Condition of the individual patient one day prior to surgery, one day after surgery, $7^{\text {th }}$ post-operative day, and $30^{\text {th }}$ post-operative day were assessed and studied. Patients were divided into two groups as per the glycosylated haemoglobin level within normal range $(4.5-6 \%$.) HbA1c $<6 \%$ and above normal (over $6 \%$ ) HbA1c $>6 \%$.

\section{Observations}

Out of 60 patients $20(33 \%)$ patients were having pre-operative level of HbAlc $>6.0 \%$ and $40(67 \%)$ patients were below an equal to $6.0 \%$. (Table: 1 )

Table: 1 Categorisation of patients as Pre op. HbA1c

\begin{tabular}{|l|c|c|}
\hline Preop. HbA1c (\%) & Number of patients(n) & Percentage (\%) \\
\hline$>6$ & 20 & 33 \\
\hline$<6$ & 40 & 67 \\
\hline
\end{tabular}

The age of patients in this study ranged between 29-76 years. The mean age of these patients were 59.5 years \& 52.3 yaers in category $\mathrm{HbA1c}>6 \%$ $\&$ HbA1c $<6 \%$. (Table: 2 ) No patient in the age group of 20-29 years in category $\mathrm{HbAc}<6 \%$.
In $\mathrm{Hb} \mathrm{A} 1 \mathrm{c}>6 \%$ out of 20 patients $12(60 \%)$ were male \& $8((40 \%)$ were female \& in $\mathrm{HbA} 1 \mathrm{c}<6 \%$ out of 40 patients $20(50 \%)$ were male $\& 20(50 \%)$ were female. (Table- 3 )

Table: 2 Pre po. HbA1c in different age group

\begin{tabular}{|l|c|c|c|c|}
\hline & HbA1c $>6 \%(n=20)$ & & HbA1c<6\% $(\mathrm{n}=40)$ & \\
\hline Age Group(yrs) & No. of patients & Percentage & No. of patients & Percentage \\
\hline $20-29$ & 01 & 05 & 0 & 0 \\
\hline $30-39$ & 01 & 05 & 02 & 05 \\
\hline $40-49$ & 03 & 15 & 16 & 40 \\
\hline $50-59$ & 05 & 25 & 07 & 17.5 \\
\hline $60-69$ & 06 & 30 & 12 & 30 \\
\hline $70-79$ & 04 & 20 & 03 & 7.5 \\
\hline
\end{tabular}


Table-3 Sex wise Pre op. HbA1c

\begin{tabular}{|l|c|c|c|c|}
\hline & \multicolumn{2}{|c|}{ HbA1C $>6 \%(\mathrm{~N}=20)$} & \multicolumn{2}{c|}{ HbA1c <6\% ( $=40)$} \\
\hline SEX & NO. Of patients & Percentage & No. Of patients & Percentage \\
\hline MALE & 12 & 60 & 20 & 50 \\
\hline FEMALE & 08 & 40 & 20 & 50 \\
\hline
\end{tabular}

In this study six (6) major gastro intestinal surgical procedures were included. In $\mathrm{HbAlc}>$ $6 \%$ maximum no. of patients $6(30 \%)$ were undergone partial gastrectomy and minimum no. of patients $1(5 \%)$ undergone APR whereas in $\mathrm{HbA} 1 \mathrm{c}<6 \%$ category maximum no. of patients $15(37.5 \%)$ were undergone truncal vagotomy with GJ+JJ and minimum no. of patients $1(2.5 \%)$ were undergone total colectomy. (Table: 4 )

Table: 4 Type of surgical procedure

\begin{tabular}{|l|c|c|c|c|c|}
\hline & \multicolumn{2}{|c|}{$\mathrm{Hb} \mathrm{A} 1 \mathrm{c}>6 \%$} & \multicolumn{2}{c|}{ HbA1c<6\% } & \\
\hline Ma jor GI surgical procedure & $\begin{array}{c}\text { No. of } \\
\text { patients }\end{array}$ & Percentage & $\begin{array}{c}\text { No. of } \\
\text { patients }\end{array}$ & Percentage & $\begin{array}{c}\text { No. of patient in } \\
\text { each procedure }\end{array}$ \\
\hline Partial gastrectomy & 06 & 30 & 09 & 22.5 & 15 \\
\hline Truncal vagotomy with GJ\&JJ & 04 & 20 & 15 & 37.5 & 19 \\
\hline Anterior resection & 05 & 25 & 05 & 12.5 & 10 \\
\hline Abdominoprineal resection & 01 & 05 & 05 & 12.5 & 06 \\
\hline Total colectomy & 02 & 10 & 01 & 2.5 & 03 \\
\hline Hemi-colecyomy(rt/lf) & 02 & 10 & 05 & 12.5 & 07 \\
\hline
\end{tabular}

In this study post-operative complications were observed in two categories of patients with regards to nine different types of complications after undergoing the above mentioned major GI surgical procedure. No. of complications were $13(65 \%)$ in $\mathrm{HbA} 1 \mathrm{c}>6 \%$ category and in $\mathrm{HbA} 1 \mathrm{c}$
$<6 \%$ category it is $8(20 \%)$. In $\mathrm{HbA} 1 \mathrm{c}>6 \%$ patients out of $13,10(50 \%)$ patients were with infection complications compare to $2(5 \%)$ out of 8 patients with complications in HbA1c $<6 \%$ category .(Table 5,6)

Table: 5 Type of surgical complications

\begin{tabular}{|l|c|c|c|c|}
\hline \multicolumn{2}{|c|}{} & \multicolumn{2}{|c|}{ HbA1c> 6\% } & \multicolumn{2}{c|}{ HbA1c <6\% } \\
\hline Complications & $\begin{array}{c}\text { No. of } \\
\text { complications }\end{array}$ & Percentage & $\begin{array}{c}\text { No. of } \\
\text { complications }\end{array}$ & Percentage \\
\hline Wound infection & 04 & 20 & 01 & 2.5 \\
\hline UTI & 03 & 15 & 01 & 2.5 \\
\hline Atelectasis & 0 & 0 & 02 & 05 \\
\hline Anastomotic leak & 01 & 05 & 0 & 0 \\
\hline Respiratory failure & 0 & 0 & 01 & 2.5 \\
\hline Cardiac failure & 0 & 0 & 01 & 2.5 \\
\hline Post-op. Ileus & 01 & 05 & 01 & 2.5 \\
\hline Stoma necrosis & 01 & 05 & 0 & 0 \\
\hline Pneumonia & 03 & 15 & 01 & 2.5 \\
\hline
\end{tabular}

Table: 6 No of patients with complications

\begin{tabular}{|l|c|c|c|c|}
\hline & \multicolumn{2}{|c|}{ HbA1c>6\% } & \multicolumn{2}{c|}{ HbA1c <6\% } \\
\hline $\begin{array}{l}\text { No. of patients with } \\
\text { complications }\end{array}$ & 13 & 65 & 08 & 20 \\
\hline $\begin{array}{l}\text { No. of patients with } \\
\text { infectious complications }\end{array}$ & 10 & 50 & 02 & 05 \\
\hline
\end{tabular}


Out of 20 patients of $\mathrm{HbA1c}>6 \%$ first bowel movement is delayed in $17(85 \%)$ but in patients of $\mathrm{HbA} 1 \mathrm{c}<6 \% 35(87.5 \%)$ patients out of40 having early first bowel movement. (table-7) Patients taking orally without any IVF is late in $17(85 \%)$ in category $\mathrm{HbA} 1 \mathrm{c}>6 \%$ out of 20 is more as compared to $5(12.5 \%)$ out of 40 in category $\mathrm{HbA} 1 \mathrm{c}<6 \%$. Out of 20 patients $15(75 \%)$ of patients stayed in hospital more than 9 days in category $\mathrm{HbA} 1 \mathrm{c}>6 \%$ whereas $10(25 \%)$ patients out of 40 stayed more than 9 days in category HbA1c < 6\%. (Table:8)

Table: 7 First bowel movement

\begin{tabular}{|l|c|c|c|c|}
\hline & \multicolumn{2}{|c|}{ HbA1c $>6 \%(\mathrm{~N}=20)$} & \multicolumn{2}{c|}{ HbA1c $<6 \%(\mathrm{n}=20)$} \\
\hline Time(post op.) & No.of patients & Percentage & No. of patients & Percentage \\
\hline EARLY(<3Days) & 03 & 15 & 35 & 87.5 \\
\hline Late(>3days) & 17 & 85 & 05 & 12.5 \\
\hline
\end{tabular}

Table: 8 Duration of hospital stay

\begin{tabular}{|l|c|c|c|c|}
\hline & \multicolumn{2}{|c|}{ HbA1c>6\% } & \multicolumn{2}{c|}{ HbA1c<6\% } \\
\hline Duration of hospital stay & No. of patients & Percentage & No. of patients & Percentages \\
\hline Early( <9 days) & 05 & 25 & 30 & 75 \\
\hline Late (>9days) & 15 & 75 & 10 & 25 \\
\hline
\end{tabular}

Post operative day 1 FBS level was increased from that of pre-operative in all the 60 cases but post-operative day1 hyperglycemia (FBS) was present in $12(60 \%)$ patients in category $\mathrm{HbA} 1 \mathrm{c}>$ $6 \%$ to $09(22.5 \%)$ patients in HbA1c < 6\%.This post-op day1 hyperglycemia is associated with complications (post-op) in 20 patients out of 21 and out of 39 patients only 1 patient present with complication $(\mathrm{P}=<0.0001)$. Post-operative day 7 \&day 30 hyperglycemia present in $10(50 \%)$
\& $8(40 \%)$ respectively in $\mathrm{HbA} 1 \mathrm{c}>6 \%$ to that of $7(17.5 \%) \& 4(10 \%)$ in $\mathrm{HbA} 1 \mathrm{c}<6 \%$. Post operatively all 60patients of study group showed increase CRP response, but 13(65\%) patients showed significant increase (more than $100 \mathrm{mg} / \mathrm{l}$ ) of $\mathrm{CRP}$ value in $\mathrm{HbA} 1 \mathrm{c}>6 \%$ category to 8 $(20 \%)$ patients of $\mathrm{HbA1c}<0 \quad 6 \%$ category $(\mathrm{P}=0.0006)$ considered to be statistically significant. (Table: 9)

Table: 9 CRP Response

\begin{tabular}{|l|c|c|c|c|}
\hline & $\begin{array}{c}\text { Significant } \\
\text { increase }(>100 \mathrm{mg} / \mathrm{l})\end{array}$ & Percentage & Increase(<100mg/l) & Percentage \\
\hline HbA1c<6\% $(\mathrm{n}=40)$ & 08 & 20 & 32 & 80 \\
\hline HbA1c $>6 \%(\mathrm{n}=20)$ & 13 & 65 & 07 & 35 \\
\hline & 21 & & 39 & \\
\hline
\end{tabular}

\section{Discussion}

In this study a total no. of 60 patients out of 110 patients were taken for study protocol and were divided into two groups as per preoperative level of glycosylated haemoglobin ( $\mathrm{HbA} 1 \mathrm{c})$, i.e.4.5$6 \%$ and over6\%. Out of 60 patients $40(67 \%)$ were below and equal to 6 percent and 20(33\%) were above $6 \%$ preoperatively. Only one third of the non-diabetic patients has raised pre-operative level ofHbA1c in this study in contrast to only a quarter of the of the non-diabetic patients or more in other studies. ${ }^{1,2,3,4}$. The age group in this study ranged between 29-76 years and the men age of the patient was 52.3 years $(\mathrm{HbA} 1 \mathrm{c}<6 \%)$ \& 59.5 years $(\mathrm{HbA} 1 \mathrm{c}>6 \%)$ which is in contrast to study of other group is on lower side probably the other study groups has taken patients of higher age group. The sex ratio in this study is 12:08 and 20:20 respectively in HbA1 $<6 \%$ and HbAlc $>6 \%$ which also differs from study of other group. ${ }^{5,6,7}$. In the present study six major GI surgical procedures were included which is similar 
to two other study groups. The total no. of complications were $65 \%$ and $20 \%$ respectively in $\mathrm{HbA} 1 \mathrm{c}>6 \%$ and $\mathrm{HbA} 1 \mathrm{c}<6 \%$ with $\mathrm{P}=0.0006$ which is extremely significant from statistical view point . The no. of patients with infection complications were $50 \%$ and $5 \%$ respectively in $\mathrm{HbA} 1 \mathrm{c}>6 \%$ and $\mathrm{HbA} 1 \mathrm{c}<6 \%$. Out of 60 patients $21(35 \%)$ patients had one or more post-operative complications of whom $15(25 \%)$ had at least one post operative complication during 30days follow up. Out of 20 patients, $17(85 \%)$ patients recorded delayed bowel movement in HbA1c $>6 \%$ and only $5(12.5 \%)$ patients showed delayed bowel movement in $\mathrm{HbA} 1 \mathrm{c}<6 \%$ group, with $\mathrm{P}=$ $<0.0001$ which is statistically extremely significant. ${ }^{8,9}$ Post operative day 1 FBS levels were increased from pre -operative blood sugar level in all 60 patients because of surgical stress, but post-op. Day1 hyperglycemia was present in $12(60 \%) \& 9(22.5 \%)$ respectively in patients with $\mathrm{HbA} 1 \mathrm{c}>6 \%$ \& HbA1c $<6 \%$ with $\mathrm{P}=0.0041$ which is statistically significant. Postoperatively all 60 patients of this study group showed increase in CRP response. The mean CRP level in HbAlc $>6 \%$ patients was $120.5 \mathrm{mg} / \mathrm{l}$ whereas in $\mathrm{HbA1c}<6 \%$ patients was $95.65 \mathrm{mg} / \mathrm{l}(\mathrm{P}=0.0006)$. Present study showed four weeks after surgery the HbA1c level was no significant different from that before surgery in either group.

\section{Conclusion}

This study showed that preoperative HbA1c level may be related to post operative hyperglycemia level. Also post operative hyperglycaemia appears prevalent among patients with no history of diabetes. Post-operative complications can be related to pre operative $\mathrm{HbA1c}$ levels. Pre operative HbA1c levels may be related to post operative recovery and 30 days overall morbidity after major gastro -intestinal surgery. This present study suggest that pre-operative HbAlc may be used to identify patients at higher risk of poor postoperative glycemic control and prediction of post operative complications, post-op. Recovery and 30 days overall morbidity after major gatro-intestinal surgery.

No source of funding

No conflict of interest

Approved by institutional ethical committee

\section{Bibliography}

1. RSSDI Textbook of Diabetes Mellitus $2^{\text {nd }}$ edition: Vol.-1 \&Vol-2.

2. Fischer master of surgery

3. British journal of surgery, vol-96 Nov. 2009.

4. MC. Graw Hill, Lange Current Medical Dignosis and Treatment 2010 56-57 1084.

5. O Sullivan, CJ Hynes X, Mahendran B Andrews EJ, Avalos G TAWLIK, s et al ,HbA1c in non diabetic and diabetic vascular patients

6. Krinsley JS. Effect of an intensive glucose management protocol on the mortality of critically ill adult patients. Mayo Clin P w2004 992-1000.

7. Soop MJ, Myrenfors P,Thorell A, Ljuv gqvist $\mathrm{O}$; Pre operative oral carbohydraye treatment attenuates immediate post operative resistance; Am J PhysioEndocrine Metab; 2001;280 E576-83.

8. Cai B, Chen F, Ji Y et al Alpha 7 cholinergic agonist prevents systemic inflammation and improves survival during resiuscitation: Cell Mol Med 2009; 13(9B): 3774-3785.

9. Ruickshank AM, Fraser WD, Burns HI et al. Response of serum interleukin -6 in patients undergoing elective surgery of varying severity ; Clin Sci 1990; 79: 161-5. 